\title{
AZ ADATMŰVELTSÉG PEDAGÓGIÁJÁHOZ
}

\section{Szerző:}

Koltay Tibor (PhD, habil.)

Eszterházy Károly Egyetem

Szerző e-mail címe:

koltay.tibor@uni-eszterhazy.hu

\section{Lektorok:}

Varga Katalin (PhD, habil.)

Pécsi Tudományegyetem

Kiszl Péter (PhD, habil.)

Eötvös Loránd Tudományegyetem

...és további két anonim lektor

\begin{abstract}
Absztrakt
A kutatási adatok egyre nagyobb fontosságra tesznek szert. Megfelelő kezelésük összetett feladat, amelyre meg kell tanítani nemcsak az egyetemi hallgatókat, hanem a kutatókat is. Ennek a pedagógiai folyamata jelenleg van kialakulóban, de már látszanak lehetséges útjai. Magját az információs műveltséggel rokon, az adatkörnyezet uralásának és egyszerűsitésének kompetenciáit magába foglaló adatműveltség alkotja, amelynek a néhány fontosabb jellemzőjét és oktatásának lehetséges kereteit mutatja be ez a dolgozat.
\end{abstract}

Kulcsszavak: kutatási adatok, adatmúveltség, információs műveltség

Diszciplína: információtudomány, kommunikáció- és médiatudomány, pedagógia

\section{Abstract \\ TO THE PEDAGOGY OF DATA LITERACY}

Research data is increasingly gaining importance. Its proper management is a complex task, therefore we need teaching the related skills not only to students, but to all researchers. The pertinent pedagogical processes are currently being developed, but their possible paths are already visible. Data literacy is a core skillset for managing data, related to information literacy. It comprises the competences needed for mastering and streamlining the data environment. This paper outlines some of data literacy's key features and possible educational frameworks.

Keywords: research data, data literacy, information literacy

Disciplines: information science, communication and media science

Koltay Tibor (2020) : Az adatmúveltség pedagógiájához. Mesterséges intelligencia - interdiszciplináris folyóirat, II. évf. 2020/1. szám. 33-44. doi: 10.35406/MI.2020.1.33 
Tudjuk, hogy a kutatók számos tudományterületen hoznak létre adatokat abból a célból, hogy azok segítségével tudják igazolni kutatási eredményeiket. Emellett analóg formájú adatok nagy tömege fog egy idő után (digitalizálás útján) digitálissá válni (Robinson, 2016, 74. o). Ennek folyományaként a legtöbb kutató munkájában meghatározó jelentősége van az adatokra alapozott gondolkodásnak, amely összekapcsolódik annak képességével, hogy az adatokat absztrakt fogalmakra fordítsák le (Davies, Fidler és Gorbis, 2011, 10. o.)

Azt viszont csak néhány éve - főként a tudományos kutatást támogató szervezetek nyomására - tapasztaljuk, hogy ezeknek az adatoknak stratégiai jelentőséget tulajdonít számos intézmény. A tudományos kutatás ugyanis egyre inkább támaszkodik a nagy kapacitású számítástechnikai eszközök használatára, ami többek között magával hozta, hogy nemcsak a publikációkhoz való nyílt hozzáférés (Open Access) jelent meg, hanem a nyilt kutatási adatokat (Open Data) magában foglaló nyílt hozzáférésû tudomány (Open Science) iránti igény is jelen van. Bár fejlődése aránylag lassú volt, a publikációkhoz való nyílt hozzáférés, minden ellentmondásával együtt viszonylag széles körben elterjedt már. A kutatási adatok esetében azonban jóval nehezebb a nyílt hozzáférést megvalósítani, mivel szükségességét nem minden országban és eltérő mértékben ismerték fel a kutatók és intézményeik, ezért elterjedtségének és fejlettsége is igen változó (Holl, 2018, 59. о.).
Az adatok megnövekedett fontossága nemcsak a kutatási adatokat érinti, ezért az adatműveltség (data literacy) iránti igény számos területen megfogalmazódott, tehát nemcsak az oktatás, hanem a munkáltatók, a kormányzatok, a nonprofit szervezetek és a kutatók is szükségét érzik, ezért az adatműveltség szakterületeken átívelő, interdiszciplináris és transzverzális fogalommá vált (Corrall, 2019). A következőkben azonban a tudományos kutatási adatok kezelésének kontextusára leszűkítve fogok róla szólni. Ugyanakkor azt sem felejthetjük el, hogy az adatműveltségi oktatási programok része a mesterséges intelligencia megismerése (Robinson és Bawden, 2017, 316. о.)

\section{Mi az adat?}

A kutatási adatok megfigyelésen, kísérleten vagy valamely hipotézis megvizsgálásán alapuló, szisztematikus (empirikus vagy elméleti jellegû) kutatás eredményeként jönnek létre a természettudományok, a társadalomtudományok és a humán tudományok területén (Pryor, 2012, 3. o.). Ezek az adatok lehetnek numerikusak és szövegalapúak, továbbá kikerülhetnek a hangok, álló- és mozgóképek sorából is. Fontos jellemzőjük, hogy specifikus célok elérése érdekében gyüjtik őket össze, tehát jól körülhatárolt kérdésekre adhatnak választ. Adatok egy meghatározott jelenség vizsgálata kapcsán, vagy hosszú időn át, szisztematikusan elvégzett, azonos megfigyelések eredményeként is létrejöhetnek (Borgman, 2012, 1064. o). 
Az adatokkal kapcsolatos szemlélet sokáig kötődött ahhoz az elképzeléshez, mely szerint azok a tudás és a bölcsesség alkotta hierarchiát jelképező piramis legalján helyezkednek el (Rowley, 2007, 164. o.). Be kell azonban látnunk, hogy az adatok és az információk közötti kapcsolat jóval összetettebb annál, mint ahogy azt korábban gondoltuk (Makani, 2015, 349. o.). Egy kevésbé a hierarchiára épülő szemlélet alapján például sokkal rugalmasabb lehet szemléletünk. Ennek megfelelően adat lehet bármi, ami szemantikai és pragmatikai szempontból megfelelő módon rögzíthető. Ráadásul, ha a hierarchiáról alkotott elképzelés alapján az adatokat információvá léptetjük elő, az értelmetlen adathalmozásához vezet (Frické, 2019, 135. o.).

Mivel a kutatási adatok kezelése sohasem csak a nyers adatokra korlátozódik, az adatok felhasználásának, újrafelhasználásának és kontextusba helyezésének fényében az adat és az információ fogalma egyébként sem áll távol egymástól (Schneider, 2013, 136. o.).

Az adatok egy sajátságos, korábban alig ismert fajtáját jelentik a nagy adatok (big data). Nagy adatnak azokat az adatokat nevezzük, amelyek feldolgozása meghaladja a hagyományos adatbázis-rendszerek és szoftverek képességeit, mivel gyűjtése és feldolgozása több idôt vesz igénybe, mint amit tolerálni tudunk (Gordon-Murnane, 2012, 31. o.).

\section{Az adatmüveltség természete}

A néha adat-információs irástudásnak, vagy adatírástudásnak is nevezett adatmúveltségnek (mint minden hasonló fogalomnak) számos definíciója van. Legegyszerűbben úgy határozhatjuk meg, mint az adatok megértésének, használatának és kezelésének képességét (Qin és D’Ignazio, 210). Ennek megfelelően adatműveltség alatt az adatkörnyezet uralásának és egyszerűsítésének képességét is érhetjük (Z. Karvalics, 2012, 13. o.).

$\mathrm{Ha}$ az előbbi lakonikus megfogalmazások helyett az adatműveltségek komplexebb formában kívánjuk megfogni, akkor azt mondhatjuk, hogy olyan készségek és képességek összege, amelyek lehetôvé teszik, hogy elérjük, továbbá etikusan használjuk a kutatási adatokat, valamint kritikusan szemlélni, értelmezni és interpretálni tudjuk azokat (Koltay, 2015, 403. o.).

Ez a meghatározás is jól mutatja, hogy az adatműveltség közeli rokona az információs műveltségnek (information literacy), amely olyan képességek együttese, amelyek ahhoz szükségesek, hogy felismerjük, mikor van szükségünk információra, képesek legyünk azt megtalálni, értékelni és hatékonyan felhasználni (ACRL, 2013). Egyik új definíciója megerôsíti az adatműveltséggel fennálló rokonságát azzal, hogy nemcsak a kritikai gondolkodás és a kiegyensúlyozott értékítéletek meghozatalának elengedhetetlen szükségességét emeli ki, hanem bármely analóg és digitális információra érvényes, ide értve a szóbeli közléseket, a képeket és az adatokat is (CILIP 2018). Ez annak a konvergenciának az eredménye, amelynek hatására a távközlés, a számítástechnika és az elektronikus média hálózati információs és kommunikációs technológiákként egyesültek (Livingstone, van Couvering és Thumin, 2008). Másképpen 
szólva, mivel a digitális környezetben mód nyilik arra, hogy újrahasznosítsuk az információs tárgyakat (Steinerová, 2010), az információs múveltség is magában foglalja az adatok használata iránti érdeklődést. Hasonló kapcsolódási pont, hogy az adatmúveltségre úgy (is) tekintetünk, mint az információs műveltség olyan manifesztációjára, amely a nagy adatok korában keletkezett (Li és tsai, 2019, 24. o).

Az információs mûveltség és számos rokonfogalma iránti igény az oktatást (is) érintő politikai, szociális és gazdasági indíttatású aggodalmak hatására régóta jelen van.

Megközelítése napjainkban gyakorlatilag lehetetlenné vált a sokféleképpen értelmezett digitális írástudás (digital literacy) figyelembe vétele nélkül. Ez akkor is igaz, ha tudjuk, hogy e két terminus a magyarra fordításkor a literacy szó a digitális írástudás esetében írástudás, az információs műveltség esetében a müveltség formában gyökeresedett meg. Ennek a rokonságnak egyik meghatározó jellemzője, hogy mindkét fogalom kapcsán fontosnak tartjuk, hogy a megszerzett információkat kritikai szemmel kell néznünk (Bawden, 2001, 228. o.). Ennek az írásnak nem tárgya az információs műveltség és a digitális írástudás közötti különbözőségek és hasonlóságok részletes elemzése. Éppen ezért az eltérések kapcsán csupán azt emelem ki, hogy az utóbbi - nevéhez híven - az informálódás digitális eszközeire koncentrál (Martin, 2006, 3. old.). Ugyanakkor óvatosan kell bánnunk vele, mert gyakran azt a leszúkítő értelmezést kapja, amely csak az információs és kommunikációs technológiák (IKT) szerepérôl hajlandó tudomást venni (Zsák, 2008). Ez a szemlélet azonban a technológiai determinizmusból eredő egyoldalúság veszélyét hordozza magában. Az információs múveltségnek, vagy a fenti értelemben vett digitális írástudásnak tehát tükröznie kell azokat az aktuális társadalmi-technikai konfigurációkat, továbbá társadalmi, ideológiai és fizikai kontextusokat, amelyek az információ és technológiai termékek használatát meghatározzák (Špiranec és Banek Zorica, 2010, 150. o.). Ne felejtsük el, hogy ennek a korszerű szemléletnek a jegyében születtek meg az információs műveltség fentebb említett meghatározásai. Az sem szabad szem elől tévesztenünk, hogy ennek a követelménynek az adatmúveltség esetében is meg kell felelnünk.

Az adatműveltség számos tényező együttese. A kialakításához szükséges készségeket és képességeket majd oktatása kapcsán fogom felsorolni. Itt csak arra térek ki, hogy szorosan kapcsolódik az adatminőség sokdimenziós kérdésköréhez (Koltay, 2015, 401. o.), amely magába foglalja azoknak a kontextusoknak és átalakításoknak a figyelembevételét, amelyek során az adatok létrejöttek (Ramírez, 2011, 21. o.). Az adatminőség része az adatokba vetett (szubjektív) bizalom, amelynek mértéke számos tényezőtől függ. Esetleges elfogultságunk és előítéleteink befolyásolják, hogy az adatokat autentikusnak ítéljük-e meg, elfogadhatónak találjuk-e felhasználásukat vagy alkalmazásukat. Hasonló természetű tényező, hogy miként ítéljük azoknak a jó hírét, akik az adatokat létrehozták. Valamivel kevésbé szubjektív az adatok érthetőségének megítélése, amihez nélkülöz- 
hetetlen, hogy az adatokat leíró dokumentáció, a metaadatok vagy az adatok eredetére vonatkozó információk formájában rendelkezésre álljon. Az adatok használhatóság megköveteli, hogy megtalálhatók és hozzáférhetők legyenek, fájlformátumuk adekvát legyen, továbbá biztosítva legyen az adatok megfelelô mértékű integritása, amely feltételezi, hogy az adatok a bitek szintjén bizonyíthatóan azonosak legyenek valamely egy korábbi, elfogadott és ellenőrzött állapottal (Giarlo, 2013, 6-7. o.).

Az adatok minőségének és vele az adatmúveltségnek fontos eleme az adatkormányzás (data governance) elveinek és gyakorlatának alkalmazása is. Az adatkormányzás ugyanis szabványosított és megismételhető folyamatokra épül, amivel átláthatóvá teszi az adatokkal kapcsolatos folyamatokat és a döntéshozatalt. Bár az üzleti szférában jelent meg, a kutatási adatokra is jól alkalmazható (Koltay, 2016, 303. o.).

\section{Az adatmüveltség oktatása}

Az adatokkal kapcsolatos teendők sorában általában az adatmûveltség oktatása az első elvégzendő feladat, amit az adatok kezelése (menedzselése), majd gondozása, végül megőrzése követ (Thomas és Urban, 2018, 402. o.). Az adatműveltségi oktatás elsődleges célcsoportját az egyetemi hallgatók jelentik, de szüksége van rá mindenkinek, aki kutatóként részt vesz valamilyen tudományos munkában.

Az adatmúveltség oktatásában felhasználható az egyetemi hallgatók információs mû- veltségi oktatásának az a követelményrendszere, amelyet az ACRL (Association of College and Research Libraries) állított össze. Ennek az alábbi pontjai felhasználhatók az adatműveltség oktatásának céljaira is (Carlson és tsai, 2011).

Az információs műveltséggel rendelkező hallgató képes:

- „meghatározni az információs igény terjedelmét,

- hatékonyan és eredményesen megszerezni a szükséges információkat,

- kritikusan értékelni az információt és annak forrásait,

- beépíteni a kiválasztott információt saját tudásbázisába,

- hatékonyan alkalmazni az információt meghatározott célok megvalósítása érdekében,

- értelmezni az információhasználatot körülvevő gazdasági, jogi és szociális problémákat,

- az információt jogszerūen és etikusan elérni és használni” (Csík, 2006, 87. o.).

Ezeknek a mondatoknak mindegyikében az információ szó, kicserélhető adatra.

Carlson és Stowell Bracke (2015, 98-99. o.) oktatási programja a következő területeken hasznosítható készségek fejlesztésére irányul:

- tervezés,

- életciklus-modellek,

- az adatok megtalálása és beszerzése,

- leírás és metaadatok

- biztonság és tárolás,

- szerzői jog és licencek,

- az adatok megosztása, 
- az adatok menedzselése és dokumentálása,

- az adatok vizuális megjelenítése,

- az adatrepozitóriumok,

- az adatok megőrzése,

- az adatok publikálása és gondozása.

A fentiek mellett, Robinson és Bawden (2017, 317-319. o.) a következő témákat emelik ki:

- az adatok által okozott túlterhelés jellemzői és hatása,

- az adatok típusai, az adatok, az információ és a dokumentumok közötti kapcsolat,

- az adatformátumok,

- az adatok elemzése és mérése,

- az adatbányászat.

Calzada Prado és Marzal (2013, 127. o.) kompetenciákra épülő listájában a következőket találjuk:

- Felismeri az adatok előállítását és újrafelhasználását magába foglaló életciklusának kontextusait;

- Felismeri a nyers adatok fontosságát, típusait és formátumait;

- Meghatározza, hogy mikor van szükség adatokra;

- Képes hozzáférni az információigényeinek megfelelő adatok forrásához;

- Kritikai szemlélettel fér hozzá az adatokhoz és forrásaikhoz;

- Meg tudja határozni és használni tudja a megfelelő kutatási módszereket;

- Képes kezelni és elemezni az adatokat;
- Tudja, hogy miként lehet adatokat válogatni, továbbá azokat más forrásokkal és előzetes ismeretekkel kombinálni;

- Képes a kvantitatív információt (specifikus adatokat, táblázatokat stb.) prezentálni;

- Etikusan használja az adatokat;

- Képes az eredményeket a tanulás, a döntéshozatal és a problémamegoldás céljaira felhasználni;

- Önmagát ellenőrizve képes ezeket a folyamatokat tervezni, szervezni.

Az adatműveltségnek a pedagógiai gyakorlatba való integrálása nem egyszerű és nem is egyértelmú, viszont erősödik az az elképzelés, hogy oktatásának az információs folyamatok társadalmi és kommunikatív vonatkozásait kell hangsúlyoznia, amit specifikus élethelyzetek kontextusában kell tennie, annak érdekében, hogy konstruktív társadalmi tevékenységek létrejöttét segítse elő. Ezrét látjuk azt, hogy az információs műveltség elméletének megújítását célzó megközelítések az információsan művelt egyének tanulását kívánják középpontba állítani, továbbá figyelmet szentelnek az információs műveltség élményszerű megélésének, az élménynek új kontextusokba való átvitelének és alkalmazásának (Cunningham és Williams, 2018, 19. o.).

Ezt figyelembe véve, néhány éve megindult egy olyan folyamat is, amely - konstruktivista alapokra építve - már meglevő tudásszerkezeteink folyamatos továbbépítésére és esetenkénti átalakítására alapozva az információs műveltség területén az információ élményszerű megélését és az erre való reflektálást, 
továbbá az élménynek új kontextusokra való átvitelét, alkalmazását kívánja középpontba állítani (Walton és Cleland, 2017, 583. o.).

Az adatmúveltségre való alkalmazás szempontjából a szociokulturális perspektíva az, amely számot tarthat figyelmünkre. Nem szabad ugyanakkor megfeledkeznünk arról, hogy ez a megközelítés (a különbségek ellenére is) nagymértékben összefonódik másik két elméleti perspektívával: a fenomenografikus megközelítéssel és a diskurzuselemzéshez kötődő szemlélettel (Limberg, Sundin és Talja, 2012, 93. o.).

Ennek a megközelítésnek az eredményeként az időben és térben is változó információs műveltséget olyan tevékenységnek tekinthetjük, amely nemcsak annak ismeretét foglalja magában, hogy miként keresünk információt, hanem arról is szól, hogy miként használjuk azt meghatározott társadalmi kontextusokban (Pilerot, 2016, 320. o.). Ez igaz az adatműveltségre is. Úgy gondolom azonban, hogy az adatmúveltség szociokulturális kontextusa - a tudományos kutatási adatok menedzselésének fent említett, szűkebb kontextusában legalábbis - jóval nagyobb homogenitást mutat, mint amit az információs múveltség esetében találunk, mivel elsősorban a tudományos kutatással szemben támasztott általános jellemzők határozzák meg, bár kétségtelen, hogy a már említett diszciplináris különbözőségek is hatnak rá.

A szociokulturális megközelítés alkalmazásával folyamatában reflektálunk az információkra (és az adatokra), majd további adatokat használunk fel arra, hogy a megszerzett tudást új kontextusokba helyezzük (Bruce és
Hughes, 2010. A2 o.). Ennek megfelelően, segítségével az adatműveltséget is összetettségében, társadalmi-kulturális gyakorlatként írhatjuk le, tehát úgy tekinthetünk rá, mint azonos helyen található és egy adott környezetben tevékenykedő emberek gyakorlatára. Amikor egy információs környezettel először szembesülünk, ösztönzést érzünk arra, hogy egy nem-lineáris folyamat során kapcsolódjunk az adott információs eszközökhöz, technológiákhoz és megegyezésekhez, és értelmezzük őket. A kutatási adatok bármilyen felhasználása és kezelése éppen arra ösztönöz minket, hogy felismerjük azokat a diskurzusokat, amelyek az adott szervezet vagy közösség tudástartományát képviselik.

A szociokulturális megközelítés a tanulás szituatív természetét is előtérbe állítja, továbbá kiemeli azt, hogy megfelelően tudnunk kell kommunikálni egy adott közöségi gyakorlat normái szerint, ami arra is vonatkozik, hogy az adott gyakorlat céljának megfelelően tudjunk fizikai tárgyakat használni, mivel a cselekvés és eszköze elválaszthatatlanok egymástól. (Limberg, Sundin és Talja, 2012, 104. o.). Itt ismét az általános és a szakterületi jellemzők kettős meghatározó jellegével találkozunk.

Az információs műveltség úgy valósul meg, hogy folyamatának első fázisában kapcsolatba lépünk az információs környezet ismeretelméleti módozataival, amelyek a szabályalapú, kanonizált, objektív és reprodukálható tudást reprezentálnak. Az ehhez az információhoz és a róla való gondolkodáshoz való hozzáférést instrumentális racionalitás irányítja és támasztja alá. Ahogy a kezdők gya- 
korlottabbak lesznek, egyre jobban elmélyülnek információs környezetükben és hálózatos formában kapcsolódnak a környezetükben már helyzetbe hozott, beágyazódott társaikhoz. Kialakul a szakértelmük, ami lehetôvé teszi, hogy saját maguk és mások tapasztalatai alapján értékeljék az információt (Lloyd, 2012, 780. o.). Az adatmúveltség elsajátításáról feltételezhetjük, hogy hasonló módon valósul meg, viszont az eltéréseket megint csak a szakterületi „frontvonalak” mentén kell keresnünk.

Érdemes számolnunk az informált tanulás perspektívájával is, mivel az az információval való interakcióra épül, lehetővé téve, hogy a felsőoktatásban tanulók megtanulják a szakterületükön létrejövő kutatásai adatok használatát. Ezt kiegészítve Maybee és Zilinski (2015, 108. o.) már adatinformált tanulásról beszél, amelyben a kutatás általános jellemzői és a diszciplináris különbözőségek kiegészítik egymást, tehát amit a szociokulturális megközelítés kapcsán mondtunk a viszonyukról, esetében is érvényes. Ennek megfelelően az adatinformált tanulás vezérlőelvei a következők:

1. Az adatok használatával kapcsolatos új tudásnak a hallgatók előismereteire és korábbi tapasztalataira kell épülnie.

2. A tanulásnak párhuzamosan kell megvalósulnia azzal, hogy a hallgatók az adott szakterület ismereteit elsajátítják.

3. A hallgatónak egyaránt meg kell ismerkednie az adatok használatával és szakterületének sajátosságaival.

Az adatmûveltség oktatása két különböző célt szolgál. Mindkettő a digitális adatok tág értelemben vett kezelésének elsajátításán alapul. Az egyik azonban az, hogy hatékony kutató legyen valakiből, a másik pedig az, hogy az adatmenedzsment szakemberévé váljon.

Kontextusa két tekintetben látszik különbözni az információs műveltségétől. Egyrészt nagymértékben kötődik egy-egy szakterülethez (Carlson és Johnston, 2015, 38. o.), másrészt esetében (egyelőre legalábbis) nem tekintjük jelentős problémának, hogy főként készségek elsajátítására irányul.

Az adatműveltség oktatása kapcsán Khan, Kim és Chang (2018) a készségek két típusát különbözteti meg. Az egyik esetében az adatműveltség az adatvezérelt döntéshozatalt szolgálja, míg a másodikban a kutatási adatokkal kapcsolatos szolgáltatásokhoz köthetők. Ebben az írásban - a korábban kifejtettekkel egyező módon - az utóbbi megközelítés dominál.

Az adatmúveltségi oktatást Corrall (2019) az „ördögi problémák” közé sorolja, mivel egyaránt jellemző rájuk az adott probléma meghatározásának nehéz volta, a többszereplős jelleg és a megoldhatatlanság. Az ördögi problémákról tudjuk, hogy valójában más problémák szimptómái, amelyekre a különbözọ" érintettek eltéröen reagálnak, ezért nehezen kezelhetök. Egyedi megoldásokat kivánnak, amelyek többnyire csak az. érintettek egy részének felelnek meg. Ezen kivül nem rendelkezünk az ilyen problémák (kész) megoldásainak végleges listájával. Maguk a problémák nemcsak összetettek, hanem más problémákekal is összefüggnek. A megoldandó feladatok menetköz̧ben változnak, és a különbözó beavatkozások nyomán ujabb feladatok merülnek fel (Cox, Pinfield és Smith, 2016, 16. o.). 
Némileg más hangsúlyokat kap, ha azt mondjuk, hogy az adatműveltség magában foglalja annak ismeretét, hogy mit is értünk adat alatt, hogy miként vonunk le adatokból következtetéseket, továbbá része, hogy felismerjük, mikor használják az adatokat félrevezetô vagy nem megfelelő módon. A fogalom magában egyesíti a kutató kettős szerepét, tehát azt, hogy egyaránt előállítója és fogyasztója az adatoknak.

\section{Összegzés}

Bár az adatmúveltség története jóval rövidebb múltra tekint vissza, mint a médiamúveltség és az információs mûveltség, egyre több figyelmet kap. Oktatása azonban még sok tekintetben az útkeresés közbeni állaptában van. Mivel azonban szükségeségét egyre többen felismerik, érdemes nemcsak az adatmûveltség természetén elgondolkoznunk, hanem meg kell vizsgálnunk azokat a módszereket, amelyek alkalmazásával a legjobb módon oktatható. A lehetséges keretek közül ígéretesnek kínálkozik szociokulturális megközelítésen alapuló pedagógiai megközelítés és a vele rokonságot mutató adatinformált tanulás.

\section{Irodalom}

ACRL (2013). Intersections of Scholarly Communication and Information Literacy: Creating Strategic Collaborations for a Changing Academic Environment. Chicago, IL: Association of College and Research Libraries,
Letöltés: 2019.09.02. Web: http://acrl.ala. org/intersections)

Bawden, D. (2001). Information and digital literacies: a review of concepts. Journal of Documentation, 57(2), 218-259. Doi: 10. 1108/EUM0000000007083

Borgman, C. L. (2012). The conundrum of sharing research data. Journal of the American Society for Information Science and Technology, 63(6), 1059-1078. Doi: 10.1002/ asi. 22634

Bruce, C. és Hughes, H. (2010). Informed learning: A pedagogical construct attending simultaneously to information use and learning. Library \& Information Science $\mathrm{R} e$ search, 32(4), A2-A8. Doi: 10. 1016/j.lisr.2010.07.013

Calzada Prado, J. és Marzal, M. Á. (2013). Incorporating data literacy into information literacy programs: Core competencies and contents. Libri, 63(2), 123-134.

Carlson, J. és Johnston, L. R. (2015). (eds.) Data Information Literacy: Librarians, Data, and the Education of a New Generation of $\mathrm{R} e$ searchers. West Lafayette, Purdue University Press.

Carlson, J. és Stowell Bracke, M. S. (2015). Planting seeds for data literacy: Lessons learned from a student-centered education program. International Journal of Digital Curation, 10(1): 95-110. Doi: 10.2218/ ijdc.v10i1.348

Carlson, J., Fosmire, M., Miller, C. C. és Nelson, M. S. (2011). Determining data information literacy needs: A study of students and research faculty. portal: $\mathrm{Li}_{\text {- }}$ braries and the Academy, 11(2), 629-657. 
CILIP (2018). CILIP Definition of Information Literacy 2018. Letöltés: 2019.09.02. Web : https://infolit.org.uk/ILdefinitionCILIP2 018.pdf

Corrall, S. (2019). Repositioning Data Literacy as a Mission-Critical Competence. In: ACRL 2019: Recasting the Narrative. Letöltés: 2019.09.02. Web: http://dscholarship.pitt.edu/36975/

Cox, A. M., Pinfield, S. és Smith, J. (2016). Moving a brick building: UK libraries coping with research data management as a 'wicked' problem. Journal of Librarianship and Information Science, 48(1), 3-17. Doi: 10.1177\%2F0961000614533717

Cunningham, V. és Williams, D. (2018). The seven voices of information literacy (IL). Journal of Information Literacy, 12(2), 4-23. Doi: 10.11645/12.2.2332

Csík, T. (szerk.) (2006). Információs müveltség és oktatásügy. Nemretkëzi Szemle. Budapest: Országos Pedagógiai Könyvtár és Múzeum. Letöltés: 2019.09.02. Web: http:/ /www.opkm.hu/download/ImOk. pdf

Davies, A., Fidler, D. és Gorbis, M. (2011). Future work skills 2020. Palo Alto, CA: Institute for the Future, 2011. Letöltés: 2019.09.02. Web: http://www.iftf.org/ our-work/global-landscape/work/futurework-skills-2020/

Frické, M. (2019). The Knowledge Pyramid: the DIKW Hierarchy. Knowledge Organization, 46(1), 33-46.

Giarlo, M. J. (2013). Academic Libraries as Data Quality Hubs. Journal of Librarianship \& Scholarly Communication, 1(3), 1-10.
Gordon-Murnane, L. (2012). Big data: A big opportunity for librarians. Online, 36(5), 30-34.

Holl, A. (2018). A nyílt kutatási adatok kezelésének három oldala. In: NETWORKSHOP 2018 konferenciakiad-vány. HUNGARNET Egyesület, Buda-pest. pp. 59-63.

Hughes, H. és Bruce, C. (2012). Snapshots of informed learning: LIS and beyond. Education for Information, 29(3-4), 253-269. Doi: 10.3233/EFI-130940

Khan, H. R., Kim, J. és Chang, H. C. (2018). Toward an Understanding of Data Literacy. In iConference 2018 Proceedings. Letöltés: 2019.09.02. Web: http://hdl. handle.net/2142/100243

Koltay, T. (2015). Data literacy: in search of a name and identity. Journal of Documentation, 71(2), 401-415. Doi: 10.1108/JD-022014-0026

Koltay, T. (2016). Data governance, data literacy and the management of data quality. IFLA Journal, 42(4), 303-312. Doi: $10.1177 / 0340035216672238$

Li, S., Jiao, F., Zhang, Y. és Xu, X. (2019). Problems and Changes in Digital Libraries in the Age of Big Data from the Perspective of User Services. Journal of Academic Librarianship, 45(1), 22-30. Doi: 10.1016/i.acalib.2018.11.012

Limberg, L., Sundin, O. és Talja, S. (2012). Three theoretical perspectives on information literacy. HUMAN IT, 11(2), 93130.

Livingstone, S., van Couvering, E. J. és Thumin, N. (2008). Converging traditions 
of research on media and information literacies: Disciplinary and methodological issues. In: J. Coiro, M. Knobel, C. Lankshear, \& D. J. Leu, (Eds.), Handbook of Research on New Literacies. Hillsdale, NJ.: Lawrence Erlbaum Associates, pp. 13-18. Lloyd, A. (2012). Information literacy as a socially enacted practice: Sensitising themes for an emerging perspective of people-in-practice. Journal of Documentation, 68(6), 772-783. Doi: 10.1108/002204 $\underline{11211277037}$

Makani, J. (2015). Knowledge management, research data management, and university scholarship: Towards an integrated institutional research data management support-system framework. VINE, 45(3), 344-359.

Martin, A. (2006). Literacies for the Digital Age. In A. Martin and D. Madigan (eds.) Digital literacies for learning. London: Facet, pp. 3-25.

Maybee, C. és Zilinski, L. (2015). Data informed learning: A next phase data literacy framework for higher education. In Proceedings of the 78th ASIS\&T Annual Meeting: Information Science with Impact: Research in and for the Community. American Society for Information Science. pp. 108111.

Pilerot, O. (2016). Connections between research and practice in the information literacy narrative: A mapping of the literature and some propositions. Journal of $\mathrm{Li}$ brarianship and Information Science, 48(4), 313-321. Doi: $\quad 10.1177 \% 2 \mathrm{~F} 0961000$ $\underline{614559140}$
Pryor, G. (2012). Managing Research Data. London: Facet.

Qin, J. és D’Ignazio, J. (2010). Lessons Learned from a Two-year Experience in Science Data Literacy Education. In International Association of Scientific and Technological University Libraries, 31st Annual Conference. Paper 5. Letöltés: 2019.09.02. Web : http://docs.lib.purdue.edu/iatul20 10/conf/day2/5)

Ramírez, M. L. (2011). Opinion: Whose role is it anyway? A library practitioner's appraisal of the digital data deluge. Bulletin of the American Society for Information Science and Technology, 37(5), 21-23.

Robinson, L. (2016). Between the deluge and the dark age: Perspectives on data curation. Alexandria, 26(2), 73-76. Doi: $\underline{10.1177 / 0955749016661067}$

Robinson, L. és Bawden, D. (2017). “The story of data" A socio-technical approach to education for the data librarian role in the CityLIS library school at City, University of London. Library Management, 38(6/7), 312-322. Doi: 10.1108/LM-012017-0009

Rowley, J. (2007). The wisdom hierarchy: representations of the DIKW hierarchy. Journal of Information Science, 33(2), 163-180. Doi: $10.1177 / 016551506070706$

Schneider, R. (2013). Research Data Literacy. In: Worldwide Commonalities and Challenges in Information Literacy Research and Practice. Springer International Publishing, 134140. pp.

Špiranec, S. és Banek Zorica, M. (2010). Information Literacy 2.0: hype or discourse 
refinement? Journal of Documentation, 66(1), 140-153.

Doi: $\underline{10.1108 / 00220411011016407}$

Steinerová, J. (2010). Ecological dimensions of information literacy. Information $\mathrm{R} e$ search, 15(1), colis719

Thomas, C. V. és Urban, R. J. (20178). What Do Data Librarians Think of the MLIS? Professionals' Perceptions of Knowledge Transfer, Trends, and Challenges. College \& Research Libraries, 79(3), 401-423. Doi: $10.5860 / \mathrm{crl} .79 .3 .401$

Walton, G. és Cleland, J. (2017). Information literacy: empowerment or reproduction in practice? A discourse analysis approach.
Journal of Documentation, 73(4), 582-594. Doi: 10.1108/JD-04-2015-0048

Z. Karvalics L. (2012). Információs kultúra, információs múveltség - egy fogalomcsalád értelme, terjedelme, tipológiája és története. Információs Társadalom, 12(1) 7-43.

Zhou, Q. (2018). Research on Scientific Data Literacy Education System. Open Journal of Social Sciences, 6(06), 187-199.

Zsák, J. (2008). A mûveltség fogalmának eredete és értelmezésének változásai. In: Varga, K. (Szerk.) A 21. sqázad müveltsége. Ekönyv az információs müveltségröl. PTE, Pécs. Letöltés: 2019.09.02. Web: http://www. lib.pte.hu/elektkonyvtar/ekonyvek/elibra $\mathrm{ry} / 21 \mathrm{szazad} /$ 